\title{
ARTICLE
}

\section{The Research of Walmart Global Expansion}

\section{Qiwei Shen*}

Lingnan University, Hong Kong, 999077, China

\begin{tabular}{|c|c|}
\hline ARTICLE INFO & ABSTRACT \\
\hline Article history & Purpose: To entering into the international market successfully, the com- \\
\hline Received: 12 December 2019 & pany ought to do all-round and in-depth research. This paper aims to \\
\hline Revised: 19 December 2019 & $\begin{array}{l}\text { study the process of Walmart's global expansion and find the solutions to } \\
\text { solve the relevant risks. Desion/Methodology/Anproach. In-denth inter }\end{array}$ \\
\hline Accepted: 9 April 2020 & views with 5 persons were conducted to collect their rankings of social \\
\hline Published Online: 16 April 2020 & media sites and the reasons for visiting each of the sites. \\
\hline
\end{tabular}

Keywords:

SWOT analysis

Transnational strategy

\section{Introduction}

$\mathrm{W}$ hen speaking of hypermarkets, many people would think of Walmart, the largest company by revenue and the largest private employer in the world. Actually, the success of Walmart, to a great extent, is due to its excellent globalization strategy, which also makes Walmart born again when its opportunities for growth in the United States getting much more restricted.

\subsection{SWOT Analysis}

The SWOT analysis is shown in Figure 1.

\subsection{The Strategy the Walmart Applied in Interna- tional Markets}

Today, the expansion of Walmart is no longer the copy of American model, it differentiates the product offering across geographic markets to account for local differenc- es, and foster a multidirectional flow of skills between different subsidiaries in the firm's global network of operations. Also, Walmart is a low-price discount retailer, low price of products is its advantage. Transnational strategy helps it simultaneously achieve low costs through location economies, economies of scale, and learning effects.

\section{The Benefits in the Walmart International Expansion}

Admittedly, the international expansion brings a lot of benefits for Walmart.

First, globalization reduces the marketing costs for the Walmart as it standardizes the certain marketing strategy in its retailing markets. Walmart can make a piece of identical advertisement for its promotion month and then simply translating ads into local languages in each market, for which each market shares the promotion fees.

Second, the international expansion brings Walmart

*Corresponding Author:

Qiwei Shen,

Lingnan University, No. 8 Castle Peak Road, Tuen Mun, New Territories, Hong Kong, 999077, China;

E-mail:1784661181@qq.com. 
Table 1. SWOT Analysis

\begin{tabular}{|c|c|}
\hline Strength & Weakness \\
\hline $\begin{array}{l}\text { - Adequate financial resources } \\
\text { - one of the first companies to promote widespread stock ownership } \\
\text { among employees } \\
\text { - Good corporate image } \\
\text { - Strong technical force } \\
\text {-a combination of efficient merchandising, buying power, and human re- } \\
\text { lations policies } \\
\text {-a leader in the implementation of information systems to track product } \\
\text { sales and inventory } \\
\text {-developed one of the most efficient distribution systems in the world } \\
\text { - Economies of scale } \\
\text { - Significant marketing share }\end{array}$ & $\begin{array}{l}\text { - Management shortcomings } \\
\text {-poor control of subsidiaries due to the globalization } \\
\text { - Bad competitive power } \\
\text {-bad price competitiveness } \\
\text {-quality problems }\end{array}$ \\
\hline Opportunity & Threat \\
\hline $\begin{array}{l}\text { - New market and need } \\
\text { - Removing market barriers with other countries }\end{array}$ & $\begin{array}{l}\text { - Competitors } \\
\text {-strong competitors such as Carrefour of France, Ahold of Holland, and } \\
\text { Tesco from the United Kingdom } \\
\text { - rapid development of e-commerce platform } \\
\text { - Difficult marketing expansion } \\
\text {-the practice protectionism of Local governments } \\
\text {-difficult to match local people's consuming habits and lifestyles } \\
\text { - Economic recession }\end{array}$ \\
\hline
\end{tabular}

more new market opportunities when the retailing market in the united states becomes saturate. In fact, by 1990 , it was hard for Walmart to gain a qualitative leap in its home market. But managing an enterprise is like rowing against the current, no progress means backwards. And for Walmart, the expansion not only breaks it dilemma, but also helps Walmart gain significant market share in global general merchandising. As of July 31, 2019, Walmart has 11,389 stores and clubs in 27 countries, operating under 55 different names ${ }^{[1]}$.

Third, globalization of markets helps level uneven income streams. By supplementing domestic sales with international sales, the company can reduce or eliminate wide variations in sales between seasons and steady its cash flow (John J. et al., 2019). When entering a new market, it is a common case that the subsidiaries or joint ventures don't balance. However, globalization of markets helps narrow or even remove the bad effect on companies' accounts for the income from other mature subsidiaries.

Forth, identifying and serving the local buyers needs would reveal potential benefits of global markets for Walmart. The entry to other markets, especially some regions have an entirely different culture, beliefs, customer and tradition, may hold back through a standardized global marketing strategy. So, it is crucial to do small modifications to better suit local tastes when entering into other markets. During the process of entering into the Asian market, Walmart signed the purchase-and-sale agreement for low-price products to provide great discount for customers which catered to the relatively low purchasing power of Asians. Obviously, this move helps Walmart open the Asian market and gains the market share gradually.

Last but not least, it is more beneficial for the development of global sustainability in the global market. Actually, not only the material resources can be recycled but also ideals can flow around the world.

\section{The Risks When Entering Other Markets and Relevant Solutions}

\subsection{The Relevant Risks for Walmart When Enter- ing Other Retailing Markets}

Although Walmart owns many competitive advantages, it meets many risks for Walmart when entering other retailing markets.

First, it is difficult for Walmart to replicate its efficient distribution system in other countries, especially some developing countries with poor infrastructure, crowded roads. All above increases logistics cost and diminishes the advantage of the distribution system.

Second, it exists potential risk when selecting and cooperating with local suppliers including logistics problem, stocking problems and so on. Thus, the price of the products sometimes losses the advantages comparing with local retailers.

Third, there were also problems with merchandise selection. People in different regions usually owns entirely different consuming habits and lifestyles. Because different cultures breed the different values, attitudes and be- 
haviors. Walmart would face plenty of stocking if it makes mistakes with merchandise selection.

Forth, some government would protect their local industries and publish strict rules for foreign companies. So, Walmart would meet big fines for its ignorance of regional rules.

\subsection{How to Mitigate These Risks and Create More Values?}

To mitigate the above risks and create move values, Walmart ought to bring out its strengths to make up for its weaknesses.

It is a must to refuse mechanically replicating its efficient distribution system. Walmart ought to do research with the infrastructure and traffic situation before open a new store. If the country has poor environment, Walmart ought to make a modification with the information and distribution system according to the local retailers' operation.
In fact, entering a new market via a joint venture could reduce risk. It is more effective for the local partner to select suppliers, as they have more experience and are familiar with the process of business. Also, they are much more familiar with the market including consumer preferences, popular products and so on.

Last but not least, comply with the rules that local government published, although it is sometimes unfair for foreign companies. In short term, Walmart could not expand market share and make large profits. But in long term, with the mild negotiation with local government, Walmart could develop its business rapidly as the restriction is gradually removed.

\section{References}

[1] John J. Wild, and Kenneth L. Wild. International Business: The Challenges of Globalization[M]. Pearson, 2019. 